\title{
An Image of Korean Women during the Japanese Occupation of the Peninsula, as It Emerges from Literary Masterpieces
}

\author{
Elena BUJA \\ Transilvania University of Braşov (Braşov, Romania) \\ Department of Theoretical and Applied Linguistics \\ elena_buja@yahoo.com
}

\begin{abstract}
This paper ${ }^{1}$ aims to offer a picture of the darkest period in the history of the Korean women, namely that of the Japanese colonial rule (1910-1945). The only advantage Korean women enjoyed as a result of their country's annexation to Japan was access to institutional education, even if this was done in Japanese and from Japanese course books. But this came with a price: many of the Korean teenaged females were turned into comfort women (sexslaves) for the Japanese soldiers before and during the Pacific War. Not only did these girls lose their youth, but they also lost their national and personal identity, as they were forced to change their Korean names into Japanese ones and to speak Japanese. To build the image of the fate of the Korean women during this bleak period, the research method I have used is a simplified version of content analysis, "an analysis of the content of communication" (Baker 1994, 267). I have explored the content of fragments from a couple of novels authored by Korean or American-Korean authors, which cover the historical events in the peninsula leading to the end of WWII (Keller's Comfort Woman (2019) and Bracht's White Chrysanthemum (2018), to mention just a few) and which are focused on the topic of comfort women, ${ }^{2}$ i.e. young women that were sexually exploited by the Japanese military. The results of the analysis indicate that many of the surviving victims became "unpersons" and led a life of solitude and misery until their death.
\end{abstract}

Keywords: Korean Peninsula, Japanese occupation, Korean women, comfort women

1 This research study was supported by the 2020 Korean Studies Grant Program of the Academy of Korean Studies (AKS-2020-R47).

2 This is a euphemistic term employed to refer to young unmarried women who were recruited as sex slaves for the Japanese military. In Japanese, they were called daishindai 'team of offering bodies' or ianfu 'comfort woman', while in Korean, chongshindae 'battalion slaves'. Frequently, these young women were referred to by the letter ' $\mathrm{P}$ ' coupled with their nationality. Thus, Korean sexual slaves were called Chom-P. "It has been suggested that the slang 'P' derives from the English initial of the word 'prostitute', but it is more likely that it comes from the vulgar 


\section{Introduction}

At present, Korea is mainly known to the world through its corporate names like Samsung, Hyundai, or LG and through its popular culture, which has turned from a local into a global phenomenon. "Yet, its remarkable modern history with its important implications is still not widely known and appreciated" (Seth $2010,3)$. This is what inspired me to bring to light one particular period in the modern history of the peninsular country, namely that of the Japanese colonial occupation of Korea (1910 to 1945).

Until the late nineteenth century, Korea prided itself in territorial unity, institutional stability, historical continuity, ethnic unity, and in its efforts to keep the kingdom free of any external influence (hence the nickname of "the hermit kingdom" attributed by Westerners). At the turn of the century, the country became the fighting ground for the world's major imperial powers. "Japan, China, Russia, the United States, and European powers competed to take control, and the Kanghwa treaty with Japan in 1876 forced Korea to abandon its long-standing isolationist policy. The country was eventually pressured to open its doors by signing treaties, but the inept government was not able to cope with the increasing tide of foreign intrusion" (Yu 1987, 62).

From among these warmongers, Japan, being the geographically closest and the fiercest of all, came out the winner. After a period of slow but continuous assimilation of Korea, the peninsular country lost its century-long independence in 1905 and became protectorate, or, more exactly, "an exploited colony" of Japan (Cumings 2005, 15). In 1910, Korea was annexed to Japan, and it remained under colonial rule until the end of WWII. The Japanese occupation of Korea marks a period of crisis, of political turmoil, of extreme poverty and humiliation for its people, who were robbed of their crops, of their belongings, of their language and alphabet (Hangeul), and of their Korean names by the Japanese. "Schools weren't allowed to teach Korean history or language. Hardly any books or newspapers were published in Korean. People weren't even supposed to tell old Korean folktales. [...] By order of the Emperor, all Koreans are to be graciously allowed to take Japanese names" (Park 2002, 3-5).

Though the annexation of Korea to the Japanese Empire was broadcast to the world as an act of favour granted by a developed Japan to its neighbouring country, in a state of feudalism at the beginning of the $20^{\text {th }}$ century, it was actually a policy of oppression.

In this paper, my intention is to sketch a picture of the Korean women during the Japanese rule, to bring to light their courage to fight against the social norms

Chinese term p'i, for vagina. It should be noted that the use of the terms ' $\mathrm{P}$ ' and comfort women was confined mainly to the military, while 'comfort women' was not so much a euphemism as a form of officialese" (Hicks 1997, 29). 
of the time being driven by their motivation to study in educational institutions, a right reserved mainly for men, as well as their sexual enslavement by the Japanese soldiers. The roadmap of the paper is the following: section 2 briefly presents the theoretical framework, i.e. content analysis, the data I have used to achieve my aim, and the research questions. Section 3 is dedicated to the analysis of fragments excerpted from six novels. I have divided this part into 2 subsections, each corresponding to one period of time of the Japanese rule. The conclusions are gathered in section 4 .

\section{Research Methodology}

The research method employed in this paper is a simplified version of content analysis, the goal of which "is never just description; rather, the analysed content must be related to [...] factors about the documents, about the persons stating the content, about the intended audience, or about the times in which the content was produced" (Baker 1994, 268).

For the current study, I have selected a sample of novels (or "content") to be analysed, which are representative for the investigated topic and which have "a clear historical time frame” (Baker 1994, 106), namely the Japanese colonization of Korea (1910-1945). They have been written mainly by authors of KoreanAmerican origin: Mary Lynn Bracht (2018) White Chrysanthemum, Annabelle Kim (2016) Tiger Pelt, Eugenia Kim (2009) The Calligrapher's Daughter, Nora Okja Keller (2019) Comfort Woman, Helie Lee (1997) Still Life with Rice, YoungSook Moon (2019) Trampled Blossoms, and Linda Sue Park (2002) When My Name Was Keoko. Though they are works of fiction, my choice for these particular novels was dictated by the fact that most of them are based on biographical information. Thus, authoress Helie Lee is the granddaughter of the main heroine in her novel Still Life with Rice. A second reason for choosing novels as primary data for my study is that the plight of comfort women was not of major concern for the historians. This issue came to light only in the early 1990s, when the first survivor of a comfort station, Kim Hak Sun publicly told the story of her life as a sexual slave for the Japanese military. "Her example gave others the courage to join her in a class action which was launched in the Tokyo District Court on 6 December 1991" (Hicks 1997, 15). Consequently, as in content analysis the researcher must rely on printed materials (Baker 1994), my only choice was to draw together information form literary masterpieces. Moreover, since these novels are culturally valued works, "they represent important aspects of the culture under study" (Baker 1994, 268), i.e. the Korean culture.

From the novels mentioned above, I have extracted fragments whose content was focused on the general topic of comfort women, with two 
sub-themes ${ }^{3}$ : a) education - the Korean girls' strong desire to have access to education, a right reserved mainly for boys in the Korean patriarchal system; b) the horrors experienced by a large number of Korean teenagers, euphemistically called comfort women, who were either selected from schools or simply abducted and sent to front-line brothels (comfort stations) to provide sex services for the Japanese soldiers during WWII.

By using a kind of jigsaw puzzle technique, i.e. putting together information from the novels under consideration, I hope to be able to provide a clear (though touching) picture of Korean women's fate during the Japanese occupation, bearing in mind a line from one of the novels, which says: "War is a man's game, but the women and children seemed to suffer the most" (Lee 1997, 211).

The research questions the paper intends to provide answers to are the following:

1) How have the historical events impacted the lives of the young Korean females in the second quarter of the previous century?

2) Will the physical and moral damage inflicted by the Japanese military to the Korean women during the colonial rule ever be acknowledged by the Japanese government and punished?

The analysis of the data will be made in chronological order: section 3.1 is dedicated to the third decade of the $20^{\text {th }}$ century, the period of time when the Japanese colonizers encouraged the education of Korean children (including girls) in an institutional setting, this being the only advantage for women during the Japanese rule in Korea; section 3.2 covers the time when Japan got involved in the Pacific War. Even if Korea was not directly involved in this world conflagration, it did suffer its effects: many Korean boys were forced to fight for the Japanese army, while many girls were sexually enslaved by the Japanese, in the so-called "comfort stations", or "recreation camps".

\section{Korean Women during the Japanese Occupation}

\subsection{The 1920s and the $1930 \mathrm{~s}$}

Maybe the only advantage the Korean women had during the Japanese colonization was access to schooling. In the patriarchal system of Korea, the virtues attributed to women were: being good daughters, good wives, and good mothers. "Education under this patriarchal value system seems to function as an important mechanism to produce a 'virtuous' woman and thus to maintain

3 In content analysis, "documents might be categorized in their totality by major themes" (Baker 1994, 268). 
the Korean patriarchal system" (Hyun 2002, 1). At the end of the Joseon ${ }^{4}$ era, education was essentially for the benefit of men. But not all women would accept this idea. Some of the young females belonging to the yangban ${ }^{5}$ families were educated at home by their own mothers or by private tutors (an example in this respect being Haejung, a female character in Kim's (2009) The Calligrapher's Daughter). They were predominantly instructed on female morality and attitudes and on household activities. Unfortunately, girls of the lowborn did not have the luxury of being educated, as they had to work in the field. In the most fortunate cases, they would receive informal training in cooking and sewing, skills that would prepare them for their future marital life. This amounted to the fact that most of the Korean women were illiterate. According to Yu (1987), in 1930, 90\% of Korean women were illiterate, while in the late 1950s illiteracy of the female population in Korea was about $80 \%$ (Seth 2010).

As a protectorate of Japan between 1905 and 1910, Korea showed willingness to carry out reforms under Japanese auspices. These reforms, known as the Kabo Reforms, were aimed at the modernization of various domains of the Korean society, including the educational system. The development of the Korean educational system was enhanced due to the establishment of ordinary schools by the colonial government all over the peninsular country. According to Toyoshima (2003, 122), "[o]rdinary schools were colonial institutions designed as a means to disseminate colonial ideologies, and played a dominant role in the education system". Initially, these schools were meant for the children of the Japanese colonizers, but, in time, Korean children were also allowed to attend them.

After the annexation of Korea to Japan in 1910, the education system was divided into primary education (four years), secondary education (four years for boys and three years for girls) or two-three years of vocational education (Oh and Kim, 2013). In the third decade of the previous century, "[t]hrough the Korean Educational Ordinance of 1922, the primary school course extended to six years for boys and girls" (Oh and Kim 2013, 115), following the Japanese model. At the same time, during the same period, secondary education was also extended to five years for boys and four for girls.

At the beginning of the Japanese rule, schools employed both Korean and Japanese teachers, but when Korea was entirely assimilated by Japan, the Japanese took over the role of teaching children, even if many of them were not qualified for such a profession. What is worth mentioning is that these ordinary schools encouraged the education of girls, irrespective of their social background. Thus, the number of Korean girls who were enrolled in such schools started to increase, although it was much lower than that of Japanese schoolgirls. According to Seth

$4 \quad$ Joseon was the former name of Korea.

5 The term yangban refers to the hereditary aristocracy in Korea, which was made up of landowners and government officials (Seth 2010). 
$(2010,38)$, "[t]he very fact that many women were attending the new schools was a sign of the radical changes in Korean society that were starting to take place".

As it emerges from Park's novel When My Name Was Keoko, "elementary students all went to the same school, but in junior high, boys and girls went to separate schools. Japanese students had their own classrooms" (Park 2002, 19). This ethnic separation is also confirmed by secondary data sources. Thus, according to Oh and Kim $(2013,115)$, "primary schools and middle schools were divided in terms of ethnic groups".

The beginning of the institutional education of Korean girls is touched upon by Eugenia Kim in her novel The Calligrapher's Daughter (2009). Haejung, the calligrapher's wife, regrets not having had the chance to study at school and is determined to help her daughter, Najin, to receive formal instruction, despite her husband's opposition. Najin's father, a staunch traditionalist, was very much against his children attending school because the classes were taught by the colonizers, the Japanese kanja was taught in lieu of Hangeul, the Korean alphabet, and Korean books were burnt or confiscated, so that the pupils were forced to study from Japanese course-books. Still, Haejung hoped that her husband would consent to sending their daughter to school, as the Japanese started building public schools, which "can teach all women, not just yangban daughters" (Kim $2009,11)$. It is very true that the educational initiative of the Japanese empire was only a plan to educate the Korean children and adolescents into becoming Japanese sympathizers. Moreover, Japanese imperialism used Korean women's education as a means of manipulating them, of spoiling the harmony in their family, and, in the long run, of destroying the society as a whole. So, Japanese education was a double-edged sword. This is evident in the following fragment excerpted from the above-mentioned novel.

I can't understand how any educated man could send his son to those teachers. Think of the lies they'll learn! [...]. Think of the propaganda those sabre-wearing quacks will spew. The pirate teachers - peasants and shopkeepers - coming here for free land and opportunities stolen from our countrymen. Think of their maps - colonist geography! Their books - imperial revisionist history! And surely nothing classic will be taught. They mean to raise a nation of ignorant collaborator sheep. (Kim 2009, 21)

Another character in Kim's (2009) novel, Deacon ${ }^{6}$ Hwang, being more openminded than the calligrapher, tries to convince him of the necessity of equal

6 At the end of the $19^{\text {th }}$ and the beginning of the $20^{\text {th }}$ century, quite a large number of Koreans embraced Christianity, the missionaries contributing to the education of girls, especially in the missionary schools. 
education rights for both boys and girls, even if the educational process is conducted by the colonizers:

Deacon Hwang: Did they [women] not shout as loud as we did? Did they not die as tragically as men? Do they not desire independence as passionately as we do?

Calligrapher Han: They've already coerced thousands of our youth to attend university in Tokyo. Our sons are forgetting what it means to be Korean! Now they'll take the women too?

Deacon Hwang: Not just Tokyo. Any worthy student, man or woman, can study in America, Germany, or France, perhaps. They (i.e. the Japanese) also plan to expand Soongsil Academy and Union Seminary in Pyeongyang. Calligrapher Han: Bribes. Means to control us! (Kim 2009, 83)

The calligrapher's suspicions were right: Japanese education for girls came with its shortcomings, as confessed by Keoko, the heroine of Park's (2002) novel:

All our lessons were in Japanese. We studied Japanese language, culture, and history. Schools weren't allowed to teach Korean history or language. [...]. My own hair had been cut short, chin-length, with bangs, when I started school, because that was the required hair style [...]. Everyday, the whole school met in the courtyard to recite the Emperor's education policy. We sang the Japanese national anthem. (Park 2002, 33-34)

What the fragment reveals is that the Koreans were not allowed to be Koreans any longer but were forced into becoming obedient servants of the Japanese emperor; in other words, they lost their national, cultural, and personal identity.

But girls' access to education came with a price. During WWII, the Japanese used schools for recruiting "female ammunition" for the soldiers in the front line. They relied on the help of chin-il-pa (literally 'lover of Japan' - Koreans who cooperated with the Japanese) and also on the school-girls' naivety, who believed in the promises made by the Japanese, namely that they would be given jobs in textile factories in Japan, where they would be provided with a place to stay and a lot of food to eat. In a period when Korea experienced acute famine, causing lots of casualties especially among children, girls could be very easily persuaded that their effort would be beneficial both for them and for their families, as illustrated by the excerpt below:

7 This is one of the many derogatory terms used by the Japanese soldiers for the women they forced into sexual slavery. 
Buntaro-san took up the megaphone. "All girls sixteen years and older, report to the northeast corner." [...] When the older girls had lined up, the principal began speaking to them. "His Divine Majesty, the Emperor is giving you girls a wonderful opportunity. There is a great need for workers in Japan, [...] making uniforms for the honorable members of the Imperial forces. A salary will be paid to your families here in Korea. It is a chance to help both the Empire and your own family! Who among you would like to volunteer for this noble cause?" (Park 2002, 96)

As sexual issues were taboo in the Korean families, none of these schoolgirls suspected anything bad, especially as the message of the schoolmaster was wrapped in such enticing terms. And although the fragment above mentions "volunteering", these poor, innocent girls were actually forced into leaving their families, without even being given the chance to go home and say good-bye to their parents. But this issue will be approached in more detail in the following section of the paper.

\subsection{Korean Girls as Comfort Women during WWII}

It is said that during hard times, women have it worst. And indeed, the worst treatment a woman could receive is to be sexually abused and tortured. This is what the Japanese soldiers did to about 200,000 Asian women, most of them Koreans, starting with 1932 until the end of WWII. The horrors these victims had gone through were brought to light only in the 1990s, when Kim Hak Sun, one of the surviving comfort women, was the first to speak out in public. A plausible reason for this long period of silence is the fact that in Korea, a society based on Confucian principles, a woman's sexual purity was extremely important. As such, comfort women chose to repress the wounds of their past and be buried with them, rather than to be discriminated against and marginalized in case the sad truth concerning their youth had been exposed. It would have meant loss of face for them, something the Koreans are very strict about. Once the fate of comfort women was revealed to the public, the issue started being investigated and deeply explored in novels (see a partial list in section 2 above).

As we have seen in the previous section, one spot the Japanese recruited comfort women from were the schools. But very often young girls were abducted from the streets of the places they lived in (Chun-ja in Trampled Blossoms), others were abducted from the beach, where they helped their mothers as haenyeo 'sea divers' (Hana in White Chrysanthemum), whereas still others were sold by family members because of the poverty they experienced (Akiko in Comfort Woman "was sold like a cow" by her eldest sister, when she was only twelve years old). In some other cases, ordered by the Japanese to fill the "positions made vacant", the city governments notified the Korean families with eligible daughters. 
Once recruited, these girls were taken to all the Japanese-occupied countries: Inner Mongolia, China (Manchuria), or the Philippines. Some of them would travel along with the front: from Mongolia to Hong Kong, then to the Philippines and, eventually, back home (as was the case of Haruko of Trampled Blossoms).

Due to the fact that the Japanese soldiers found it easier to use Japanese names, once the girls arrived at the comfort stations, their Korean names were replaced by Japanese ones. Moreover, the girls were also assigned numbers. This is revealed in Chun-ja's recollection of the first day in the recreation camp: "The first thing you need to do is memorize your number. Your numbers will be assigned from the youngest to the oldest. Number 1 is Haruko, Number 2 is Fumiko, Number 3 is Akiko, number 4 is Junko. So from now on, your name is Haruko, Number 1. Got it?" (Moon 2019, 61).

This procedure deprived the girls not only of their nationality and personal identity but also of any kind of human traits: they were not people but numbers that Japanese soldiers could play with.

The terrible life of comfort women in the recreation camps is very difficult to put into words. In these places, girls as young as twelve or thirteen years of age had to serve a large number of soldiers a day - in between twenty (Bracht 2018) to forty (Moon 2019) -, six days a week. The regular soldiers got thirty minutes with the girls, while the officers an hour. And the longer the lines of "customers" grew, the more violent they became with the comfort women.

Despite the fact that the girls were instructed on how to stay away from being infected with venereal diseases or becoming pregnant, as the number of soldiers they had to "accommodate" daily was quite high, these two dangers were often difficult to fight. Many of the comfort women died because of the complications brought about by the diseases they got, which caused their crotch to rot (Moon 2019). The treatment applied by the Japanese to those that survived the venereal disease is unimaginable for human beings. When the officers of the recreation camps realized that the comfort women were infected and, thus, useless, they would take them out of the camp under the pretext that they were "transferred", but actually they abandoned them in the forest. In other camps, the girls who got the venereal diseases were not provided food any longer and were left to die (Moon 2019). Others were simply shot. When Akiko, the heroine of Comfort Woman (Keller 2019) became pregnant, the doctor gave her a choice: rat poison or the stick. Witnessing the horrible death of another comfort girl, who had chosen the rat poison to abort her baby, Akiko went for the latter. Without being given any anaesthetic, her foetus was pulled out of her womb with a stick. And as if this physical pain was not excruciating enough, she also has to endure an even worse one. As a thirteen-year old girl, all she wanted was to get back to her family, and this made her beg the doctor who performed the abortion to help her have the wish fulfilled. "But he only laughed and pushed himself on top of me, using my 
body as the other soldiers had done. Afterwards, as he wiped himself on my shirt, he opened the screen partition and let others watch him examine me. 'This one is still good', he called over his shoulder. He pried the lips of my vagina open with his fingers. 'See?', he said. 'Still firm and moist'” (Keller 2019, 35).

Many of the comfort girls could not endure the physical and psychological pain and tried to either resist the abuse of the Japanese soldiers, to flee the camps, or even to commit suicide. The punishment they received is difficult even to read about: they were "skewered from vagina to mouth, like a pig ready for roasting" (Keller 2019, 21), beaten on their breasts with hot spatulas, or even "seared on the chest with a red-hot iron", like cattle (Moon 2019, 128).

Eventually, WWII came to an end, and Japan surrendered. During the retreat from the zones they occupied, the Japanese soldiers tried to wipe away any trace of their criminal acts committed against many Asian women. They slaughtered not only the comfort women but also the Korean soldiers who had been forcefully conscripted in the Japanese army. When it came to the means of getting rid of the comfort women, the Japanese were as imaginative as they were in punishing the girls for resisting them. "They killed all the comfort women. Then they stacked up their corpses, poured kerosene on them, and set them on fire" (Moon 2019, 126). In other cases, "they herded a group of comfort women into a cave and blew them all up with grenades" (Moon, 2019, 171). The following fragment illustrates the cold-bloodedness of the Japanese soldiers:

At length, the sergeant in charge of the girls rousted them from the tent. He marched them into a hole in the ground circled by sandbags. He ordered them to hunker down for an impending air strike and left them quaking there. [...] They knew, as animals would, that they were in mortal danger. They hugged each other in the tight confines of the earthen bunker. After an hour, the same sergeant, accompanied by two soldiers armed with machine guns, returned to the dugout. [...] The soldiers opened fire into the dugout. The girls' screaming stopped quickly. But the machine gun fire continued at excruciating length. (Kim 2016, 76-77)

The comfort women who managed to survive, i.e. the heroines of the novels considered in the analysis, had mixed feelings related to their freedom. On the one hand, they all longed to return home, to their families, and they were convinced they deserved to be happy because they had suffered so much from the brutality of the war. On the other hand, even if they were aware of the fact that they were just innocent victims, they felt ashamed and were afraid of their parents' reaction at finding out that they had been used as "public toilets" ${ }^{8}$ by the Japanese:

8 Another derogatory term employed by the Japanese in referring to the comfort women. They also called them "sacred latrines". 
Chung-ja (Haruko): How am I going to look Mom in the eyes? What am I supposed to tell her? [...] Given everything my mom had gone through, I couldn't bring myself to reveal my own wounds. I couldn't tell her that her daughter's womanhood had been taken from her.

Sam-rye (Akiko): I'd rather not go back. I can't face my mom like this, let alone the rest of my family. (Moon 2019, 210-219)

The reactions of the family members on seeing the girls at home after such a long time differed from case to case. Some mothers were more understanding and welcomed their daughters whole-heartedly, realizing that they were not to be blamed for their tragedy. But in many situations the victims of the Japanese soldiers would be cast out like pariahs. The fragments below illustrate the two attitudes:

Chung-ja's mother: You didn't do anything wrong. It's all the fault of this wicked world. What can we do aside from going on with our lives? You can tell me anything. Hiding the pain inside will just make it worse. You need to let go of those awful memories and make a new start. (Moon 2019, 223)

Lee Hanah's mother: The woman raised her hand over the shoulder and paused in this position for a moment as if to gather all the strength of her horror and rage and pain. Then she slammed a backhand down on her daughter's face. The little girl hurtled to the floor. She closed her eyes and lay still as a grave, as she had done so many times before. She heard her mother scream again and again: 'You should have killed yourself!' (Kim 2016, 102)

One could not help but sympathize with Lee Hanah, first and foremost for the tormenting endeavour of opening up to her mother, telling her how she had been kidnapped, taken to a comfort station in China, marched back to Korea after the end of the war, and how she was the only girl who survived the shooting of the comfort women by the Japanese. On the other hand, we could also figure out the reasons behind her mother's reaction. It was not because of the lack of love that she behaved like that towards her daughter but rather out of too much love. She knew exactly that in the Korean society a woman who had been defiled outside marriage was marginalized. At the same time, Lee Hana's mother was sure that victims of such a tragedy would never lead a normal life, a pain too great for a parent to endure. And it is very true that most of the women who survived their enslavement tried to hide away from the world, living in seclusion, or suffered from mental illnesses (Kim Soon-Hyo / Akiko in Keller 2019). The "lucky" ones would marry widowers with children (as was the case of Chung-Ja / Haruko in Moon 2019), impotent men, who wanted to save their face by marrying any woman, irrespective of her social 
condition or her past (this being the case of Lee Hanah, Kim 2016), or American missionaries (Akiko in Keller 2019), who, as servants of God, were more lenient in terms of the sexual past of their wives. As Bok-sun, one of the comfort girls in Moon's novel, put it, "[w]e have to keep quiet about everything we went through. Who could tell about the horrible things we suffered? Only the sky above us and the earth below will know the truth" (Moon 2019, 184).

And indeed, the families of our main characters never learned of their tragic stories while the women were still alive. Akiko, the heroine of Keller's Comfort Woman, made an indirect confession of her ordeal via a recording. Her daughter found the tape in a box, together with other things, such as a note with Akiko's Korean name, only after the death of her mother. By listening to the recording a number of times, she could identify the secret Akiko did not have the courage to reveal while alive:

Chongshindae [Battalion Slave]. Our fathers and brothers conscripted. The women left to be picked over like fruit to be tasted, consumed, the pits spit out as Chongshindae, where we rotted under the body of order from the Emperor of Japan. Under the Emperor's orders, we were beaten and starved. Under the Emperor's orders, the holes of our bodies were used to bury their excrements. Under the Emperor's orders, we were bled again and again until we were thrown into a pit and burned. (Keller 2019, 193)

Old Chung-ja, the heroine of Moon's Trampled Blossoms (2019), disappeared from the home she had been sharing with her daughter's family. Three years after she had been reported missing, the family got a phone call from the House of Sharing, a shelter for the victims of Japanese military sexual slavery, informing them that Heo Chung-ja had passed away. Everybody was wondering why grandma Chun-ja had chosen to spend her last days in this place. The only possible reason was that she had been a comfort woman, an experience she had kept silent about for fear that her daughter's and her granddaughter's lives would be affected. In the three years she spent at the House of Sharing, she put down her life experiences in a book, which came out two days after her death.

Three of the novels that served as sources of information for this paper bear very suggestive titles: White Chrysanthemum is the symbol of mourning - all the surviving victims mourned for their lost lives, as well as for their friends from the recreation camps who had departed to Heaven. Trampled Blossoms makes the reader think of the dreams of the sexual slaves that were crushed while they were young girls, "before they had a chance to bloom" (Moon 2019, 244). Keller's Comfort Woman leaves no room for interpretation. All of them represent a humble tribute paid to the victims of sexual slavery under the Japanese occupation and a message that such crimes should not happen again. 


\section{Conclusions}

The analysis of the fragments excerpted from the seven novels indicated in section 2 sought to find answers to two research questions, the first focusing on the impact of the historical events in the second quarter of the $20^{\text {th }}$ century on the lives of young Korean females. As we have seen, the Japanese colonial domination had a devastating impact on Korea in general and on Korean women in particular. The lives of the girls who were forced into sexual slavery by the Japanese military were totally destroyed. Some of them could not endure the thought of being dishonoured and the brutal treatment of the Japanese soldiers and chose to commit suicide either by hanging or slashing themselves or by drinking quinine. Those who survived suffered from mental alienation that prevented them from integrating into the society. They were marginalized by their own families for fear that their tragic past would "contaminate" all their relatives. They had no prospect for marriage, not to mention for becoming mothers, because many of them suffered brutal mutilation of their intimate organs. As they were of school age when they became comfort women, these girls could not finish their education, a dream made possible but also soon shattered by the Japanese. Thus, many remained almost illiterate, which reduced their chances of finding a job. All this shows how an act like the one committed by the Japanese could turn a human being into an "unperson".

The answer to the second research question concerning the acknowledgement by the Japanese government of the damage inflicted on Korean women and the official apology addressed to them is more problematic. Initially, the "[l]iving victims were too intimidated to challenge the might of the Japanese state" (Hicks 1997, 10) immediately after the end of WWII. Then, the "desire to hush up shameful things rather than embarrass family members - a concept typical in most Asian societies" (Peterson and Margulies 2010, 173) - may also account for the women's long silence. Moreover, as Hicks stated:

Then as now, rape was never an easy charge to sustain. Given the high moral value attached to chastity, the comfort women invariably emerged from their wartime experiences defiled, yet unable to accuse their abusers. They had everything to gain by keeping silent and everything to lose by making accusations. From the patriarchal point of view, it was seen almost as a kindness to the comfort women to pretend that this systematic brutalisation had never taken place. (1997, 34-35)

On the other hand, the Japanese took all measures to cover up the atrocities committed during the war by mass killing the comfort women - as we have seen in the fragment excerpted from Kim's (2016) novel - or by attaching them as 
nurses to local hospitals (Hicks 1997). At the same time, they also seem to have burned all the documentary evidence. Thus, the Japanese government strongly denied any knowledge of the existence of comfort stations and of the sexual exploitation of teenaged girls by Japanese troops. But many sources prove the contrary. Thus, Peterson and Margulies $(2010,172)$ point out that "[t]he Japanese imperial army first developed its system of 'comfort stations' at the request of Okamura Yasuji, Vice Chief of Staff of the Shanghai Expeditionary Force”, in order to prevent the Japanese soldiers from raping the local women and from contracting and spreading venereal diseases. The same authors, just like Hicks (1997), also acknowledge professor Yoshiaki Yoshimi's major contribution to the revelation of the truth concerning the sexual enslavement of Asian women by providing documents from the archives, which proved that members of the highest level of the Japanese government had authorized the act. Jinwung Kim (2012, 349-350) stated that "the orders to recruit these so-called comfort women came from the highest echelon of the Japanese government, including the highest military authorities, and recruiters were the Japanese police and local government officials".

In the late 1990s, after Kim Hak Sun spoke publicly about the brutal and dishonourable treatment she had endured, more and more victims came into the open with their life stories. As a consequence, women's organizations in Korea (and in all the other countries from which the Japanese military abducted young women to sexually exploit them) brought the case to the public and urged the government to demand apologies and financial compensations from Japan. In 1995, cornered by the world on the basis of hands-on evidence provided by professor Yoshiaki Yoshimi and of the confessions of the surviving comfort women, the Japanese government issued an apology and promised financial compensation for the war victims. Apparently, the Japanese perpetrators of the comfort station system remained unpunished. This stirred the rage of the Korean feminists who faithfully continue the so-called Wednesday demonstrations ${ }^{9}$ every week in front of the Japanese Embassy in Seoul. "The Wednesday Demonstrations have been held every week since the first so-called comfort woman came forward twenty years ago, though $\mathrm{Emi}^{10}$ has only attended once a year for the last three years. The demonstrations call for justice, for the Japanese government to admit their war crimes committed against thousands of women during WWII" (Bracht 2018, 79).

Additionally, the Statue of Peace, a golden bronze artwork representing a young girl forced into sexual slavery by the Japanese imperial military, was placed in

9 The first demonstration was held in January 1992 (Bracht, 2018).

10 Emi is the younger sister of Hana, a sea diver who accepted to become a comfort woman only to save her sister. Realizing Hana's sacrifice, Emi's entire life is haunted by her sister's spirit. In December 2011, towards the end of her life, Emi starts participating in the Wednesday demonstrations, hoping to find her sister or get at least some bits of information about her. 
front of the Japanese Embassy in the capital city of South Korea in 2011 to remind the Japanese politicians that they had not kept their promise.

According to an article posted in The Korea Times on the 16 February 2021, currently there are only fifteen registered survivors of the recreation camps set up by the Japanese military during WWII. They are still fighting to obtain an official apology from the Japanese government for the crimes committed against them during WWII. As Lee Yong-soo, aged 93, one of the surviving victims stated, "I am not asking for money for compensation, but for the Japanese government's full acknowledgement of its crimes and an apology to the victims." Hopefully, her wish will be granted while she is still alive.

\section{Works Cited}

Baker, Therese L. 1994. Doing Social Research (2 ${ }^{\text {nd }}$ ed.). New York, London, Tokyo: McGraw-Hill, Inc.

Bracht, Mary Lynn. 2018. White Chrysanthemum. London: Vintage.

Cumings, Bruce. 2005. Korea's Place in the Sun. A Modern History (updated edition). New York and London: W.W. Norton \& Company.

Hicks, George. 1997. The Comfort Women. New York and London: W. W. Norton \& Company.

Keller, Nora Okja. 2019 [1997]. Comfort Woman. London and New York: Penguin Books.

Kim, Annabelle. 2016. Tiger Pelt. USA: Leaf Land LLC.

Kim, Eugenia. 2009. The Calligrapher's Daughter. London and New York: Bloomsbury Publishing.

Kim Jinwung. 2012. A History of Korea. From "Land of the Morning Calm" to States in Conflict. Bloomington: Indiana University Press.

Lee, Helie. 1997. Still Life with Rice. New York: Touchstone.

Moon, Young-Sook. 2019. Trampled Blossoms. What They Stole from Grandma. Transl. David M. Carruth. Irvine, CA: Seoul Selection U.S.A. Inc.

Oh, Seong-Cheol and Ki-Seok Kim. 2013. "Expansion of Elementary Schooling under Colonialism: Top Down or Bottom Up?" In Colonial Rule and Social Change in Korea, 1910-1945, eds. Lee, Hong Yung, Yong Chool Ha, and Clark W. Sorensen, 114-139. Seattle \& London: University of Washington Press.

Park, Linda Sue. 2002. When My Name Was Keoko. Boston, New York: Sandpiper. Peterson, Mark and Phillip Margulies. 2010. A Brief History of Korea. New York: Infobase Publishing.

Seth, Michael J. 2010. A Concise History of Modern Korea. From the Late Nineteenth Century to the Present. New York and Toronto: Rowman \& Littlefield Publishers, Inc. 
Toyoshima, Shino. 2003. "State Schools and the Local Community in Colonial Korea”. International Journal of Korean History vol. 5, no. 1: 119-140.

Yu, Eui-Young. 1987. "Women in Traditional and Modern Korea". In Korean Women in Transition. At Home and Abroad, eds. Yu, Eui-Young and Earl H. Phillips, 14-88. Los Angeles: Center for Korean-American and Korean Studies, California State University (epub).

\section{Web Sources}

Hyun, Kyungmi. 2002. "Life since Then: Reconstructing Korean Women's Educational Experiences and Their Lives". Adult Education Research Conference. https://newprairiepress.org/aerc/2002/papers/27 (Last accessed 3 March 2021).

Victim Asks Seoul to Bring Wartime Sex Slavery Issue to International Court of Justice. https://www.koreatimes.co.kr/www/nation/2021/02/120_304102. html?utm_source=push\&utm_medium=web\&utm_campaign=National, posted: 16.02.2021, 12:47 (Last accessed 16 February 2021). 